\title{
Rooting induction of different Lavandula angustifolia accessions by auxin application
}

\section{Indução de enraizamento em diferentes acessos de Lavandula angustifolia por meio de aplicação de auxina}

\author{
Claudine Maria de Bona ${ }^{1 *}$; Magda Aparecida Maia Masetto²; \\ Cícero Deschamps ${ }^{3}$; Luiz Antonio Biasi ${ }^{3}$
}

\begin{abstract}
Lavandula angustifolia Miller (lavender), considered a hard-to-root species, is comprised of many varieties and horticultural forms, and genotypes from different provenances may present variance in rooting capacity. The objective of this experiment was to test different concentrations of indol-3butyric acid (IBA) on rooting of eight (G1 to G8) L. angustifolia genotypes from different provenances. Cuttings were treated with different doses $\left(0\right.$ to $\left.2000 \mathrm{mg} \mathrm{L}^{-1}\right)$ of IBA. Rooting percentage (RP), root number $(\mathrm{RN})$, and length of the longest root (RL) were evaluated. The different accessions presented very diverse response to IBA application. IBA did not exert influence on rooting of G1, G2, and G7; was beneficial to G3 until $700 \mathrm{mg} \mathrm{L}^{-1}$; was beneficial to G4 and G6; and was prejudicial to G5 and G8; the same IBA dose which promoted better rooting on G3 (700 mg L-1) was toxic to G5; $1500 \mathrm{mg} \mathrm{L}^{-1}$ of IBA promoted better rooting, greater root number and length on G6 but was completely and significantly detrimental to G8. G1 and G3 presented high rooting percentages, in spite of L. angustifolia being considered a hard to root species. G4, G5 and G6, however, presented very poor rooting, compared to the other genotypes. Necessity of auxin application and adequate dose may not be generalized to $L$. angustifolia different accessions. Its use should be incentivized when the genotype is recalcitrant to root and auxin concentration should be adjusted to it.
\end{abstract}

Key words: Lavender, cutting propagation, indol-3-butyric acid (IBA), genotypes, precedence

\section{Resumo}

A Lavandula angustifolia Miller (alfazema), considerada de difícil enraizamento, apresenta muitas variedades e formas horticulturais, e genótipos de diferentes procedências podem apresentar variação na sua capacidade de enraizamento. O objetivo deste experimento foi testar diferentes concentrações de ácido indol butírico (AIB) no enraizamento de oito genótipos (G1 a G8) de L. angustifolia de diferentes procedências. Estacas foram tratadas com diferentes doses $\left(0\right.$ a $\left.2000 \mathrm{mg} \mathrm{L}^{-1}\right)$ de AIB. Porcentagem de enraizamento $(\mathrm{RN})$, número de raízes $(\mathrm{RN})$ e comprimento da maior raiz (RL) foram avaliados. Os diferentes acessos apresentaram diferentes respostas à aplicação de AIB, que não influenciou no enraizamento de G1, G2 e G7; foi benéfica para G3 até $700 \mathrm{mg} \mathrm{L}^{-1}$; benéfica para G4 e G6; e prejudicial para G5 e G8; a mesma dose de AIB que promoveu melhor enraizamento em G3 (700 $\left.\mathrm{mg} \mathrm{L}^{-1}\right)$ foi tóxica para G5; $1500 \mathrm{mg} \mathrm{L}^{-1}$ de AIB promoveu melhor enraizamento, maior número e comprimento de raízes em G6 mas foi completamente e significativamente prejudicial para G8. G1 e G3 apresentaram altas taxas de enraizamento, apesar da L. angustifolia ser considerada espécie de difícil enraizamento. G4,

${ }^{1}$ Eng $^{\circ}$ Agr $^{\circ}, \mathrm{PhD}$, Pesquisadora do Instituto Agronômico do Paraná, IAPAR. Curitiba, PR. E-mail: debona@iapar.br

2 Química Ind., Mestre em Agronomia, Dept ${ }^{\circ}$ de Fitotecnia e Fitossanitarismo, Universidade Federal do Paraná, UFPR. Curitiba, PR. E-mail: magdamasetto@ufpr.br

3 Eng $^{\circ}$ Agr $^{\circ}$, Prof. Dr. do Dept ${ }^{\circ}$ de Fitotecnia e Fitossanitarismo, UFPR. Curitiba, PR. E-mail: cicero@ufpr.br;biasi@ufpr.br

* Corresponding author 
G5 e G6, todavia, apresentaram enraizamento deficiente quando comparados aos outros genótipos. A necessidade de aplicação de auxina e a dose adequada não podem ser generalizadas para diferentes acessos de L. angustifolia. O uso de auxinas deve ser incentivado quando o genótipo é de difícil enraizamento e a dose deve ser ajustada para o genótipo de interesse.

Palavras-chave: Lavanda, estaquia, ácido indol butírico (AIB), genótipos, procedências

\section{Introduction}

Lavandula angustifolia Miller (lavender), in the Lamiaceae family (Labiatae), is a very aromatic small perennial shrub (30 to $70 \mathrm{~cm}$ tall), with basal ramifications and leaves which usually present a green-grayish color. The species is comprised of many varieties, horticultural forms and hybrids, with flower colors ranging from deep purple to white (TYUB; KAMILI; SHAH, 2007; BEUS, 2006). It is native from Europe and is usually well adapted to drier weather and higher altitudes (above $1800 \mathrm{~m}$ ), but it has been cultivated in various temperate climate regions around the world (BIASI; DESCHAMPS, 2009; LORENZI; MATOS, 2002).

L. angustifolia, the English lavender, formerly classified as Lavandula vera or Lavandula officinallis, is considered an excellent rosmarinic acid producer and the best quality lavender species because of its great quality essential oil, which is the most valued in the whole Lavandula genus due to its high linalil-acetate and linalool contents and freeness of camphor, present in other Lavandula species and hybrids (PAVLOV et al., 2005; CAVANAGH; WILKINSON, 2002; FIORENO, 1997).

Lavender may be propagated from seeds, but growth is slow and the plants exhibit too much variation in growth rate and oil composition. Furthermore, seed propagated lavender crops lack plant stand uniformity, complicating cultural practices and failing to deliver the species' worldwide demanded superior quality essential oil. On the other hand, asexually propagated Lavandula species, especially the angustifolia, present poor rooting (TYUB; KAMILI; SHAH, 2007; MOON; WILKINSON; CAVANAGH, 2006; SUDRIA et al., 2001).
Phytohormones are known to trigger different responses in plants as well to affect other metabolic pathways. Auxins, for instance, can stimulate cell division and cell elongation and also controls lateral and adventitious root formation (MISHRA et al., 2009), since a link between auxin and the activation of cell divisions in the pericycle is required for lateral root initiation (FRANCIS; SORREL 2001). Exogenous application of growth regulators such as the indol-3-butyric acid (IBA) increases the tissues pre-existent endogenous auxin and promotes rooting (PASQUAL et al., 2001). Since IBA is highly effective in stimulating rooting due to its lower mobility and higher chemical stability in the plant tissue (HARTMANN et al., 2002), it may speed the root initiation process up, as well as to increase percentage of rooted cuttings and the number of formed roots per cutting (FACHINELLO; HOFFMANN; NACHTIGAL, 1995).

The objective of this experiment was to test different concentrations of IBA on rooting of $L$. angustifolia genotypes' cuttings from different provenances, since it is important to consider possible variability in rooting response from same species plant materials from different origins in order to assess their suitability to a required cultivation region or climate.

\section{Material and Metods}

Different accessions of L. angustifolia, from provenances such as Brazil (different municipalities of Santa Catarina and Parana States), France and Germany were cultivated in a greenhouse pertaining to the Plant Sciences Department in the Agrarian Sciences Sector of the Federal University of Parana (UFPR), in Curitiba, Parana, Brazil. Herbaceous 
cuttings with $8-12 \mathrm{~cm}$ in length and around $1 / 3$ of leaf retention (apical part) were collected from L. angustifolia stock plants originally obtained from eight different provenances and named as follows: G1, G2, G3, G4, G5, G6, G7 and G8 (Table 1). Number and size of cuttings depended on the amount of plant stock material available. Cuttings had their bases submerged into different concentrations of powdered IBA diluted in deionized water for 30 seconds and placed in Plantmax $\mathrm{HT}^{\circledR}$ filled polystyrene foam trays in a completely randomized experimental design with 3 replications and kept under intermittent mist system. After forty days, rooting percentage (RP), root number $(\mathrm{RN})$, length of the longest root (RL) were evaluated. The number of cuttings per parcel, size of cuttings in $\mathrm{cm}$, different IBA concentrations in $\mathrm{mg} \mathrm{L}^{-1}$, as well the provenance of the different $L$. angustifolia accessions can be observed in Table 1. Rooting was evaluated forty days after the experiment installation since the species is considered a hard-to-root species and a longer period in the substrate would probably induce a more suitable rooting. A 30-day period is normally sufficient to allow desirable root formation on more herbaceous medicinal or ornamental genotypes (LOSS et al., 2008; BLYTHE et al., 2003).

Table 1. Number of cuttings per parcel, size of cuttings in $\mathrm{cm}$, IBA concentrations in $\mathrm{mg} \mathrm{L}^{-1}$ and provenance of the different Lavandula angustifolia accessions.

\begin{tabular}{|c|c|c|c|c|}
\hline Code & $\begin{array}{l}\text { Number of } \\
\text { cuttings per } \\
\text { parcel }\end{array}$ & $\begin{array}{l}\text { size of cuttings } \\
(\mathrm{cm})\end{array}$ & $\begin{array}{l}\text { IBA concentrations } \\
\left(\mathrm{mg} \mathrm{L}^{-1}\right)\end{array}$ & $\begin{array}{l}\text { Provenance of the different L. angustifolia } \\
\text { accessions }\end{array}$ \\
\hline G1 & 8 & 12 & $0,1500,2000$ & Stock plants from São Joaquim, SC, Brazil \\
\hline G2 & 8 & 8 & $0,1500,2000$ & Stock plants from São Joaquim, SC, Brazil \\
\hline G3 & 8 & 8 & $0,700,1500,2000$ & $\begin{array}{l}\text { Stock plants from seeds from Germany. } \\
\text { Heilpflanzen's }\end{array}$ \\
\hline G4 & 8 & 10 & $0,700,1500,2000$ & $\begin{array}{l}\text { Stock plants, cv. Elegance Ice, from São } \\
\text { Joaquim, SC, Brazil }\end{array}$ \\
\hline G5 & 4 & 12 & $0,700,1500,2000$ & Stock plants from Pinhais, PR, Brazil \\
\hline G6 & 5 & 10 & $0,700,1500$ & $\begin{array}{l}\text { Stock plants, cv. Elegance Ice, from seeds } \\
\text { from Canada; Richters's }\end{array}$ \\
\hline G7 & 8 & 10 & $0,700,1500$ & $\begin{array}{l}\text { Stock plants from a different lot of seeds from } \\
\text { Germany. Heilpflanzen's }\end{array}$ \\
\hline G8 & 4 & 8 & $0,1500,2000$ & Stock plants from São Joaquim, SC, Brazil \\
\hline
\end{tabular}

The data were analyzed by ANOVA and those with statistical differences were submitted to Tukey's test at 5\%.

Source: Elaboration of the authors.

\section{Results and Discussion}

Response to IBA was different among the different $L$. angustifolia accessions with some of the variables influenced, beneficially or not, by the auxin treatment (Tables 2-4), showing that the recommendation of use and doses of auxin to induce rooting in a species cannot be generalized and must be adjusted to different accessions/ genotypes. This response was expected. Giakountis et al. (2010) observed different responses in flowering of Arabidopsis plants submitted to different daylengths. Chivers and Aldous (2005) observed differences among Microlaena stipoides, a native grass, accessions for both reproductive and vegetative characters, but a uniform response to nitrogen treatment. Atroch, Cravo and Santos (2007) observed genetic variability on rooting percentage of cuttings of guarana clones. Some species, mainly 
if geographically widely spread, have sufficient genetic variability to allow investigations of genotype $\mathrm{x}$ environment interactions (EHLERT; HINCHA, 2008). Different precedence and consequently diverse soil and climatic conditions may be responsible by distinct internal compounds concentrations among plant genotypes and it is known that increasing concentration of glucose not only controls root length, root hair and number of lateral roots (PIO et al., 2003). A few studies have also provided significant evidence of interactions between sugar and phytohormone response and other metabolic pathway as demonstrated by reports in Arabidopsis providing evidence that these two signaling pathways interact with each other (MISHRA et al., 2009).

In Microlaena stipoides, a native grass, there were different responses to irrigation for both reproductive and vegetative characters among different accessions, but responded the same way to number of spikelets produced (CHIVERS; ALDOUS, 2005). Rooting ability in Pongamia pinnata was linked to its genotype and other contributing factors and auxin application influenced the rooting behaviour in mature stem cuttings of 10 different accessions growing in their natural habitat, maybe due to differences in physiological state of the individual during collection and endogenous hormone levels, besides genotype (KESARI; DAS; RANGAN, 2010).

The presence of auxin did not influence rooting on G1. Rooting percentage was considered good, ranging from $80 \%$ to $100 \%$, with 20 roots, 10 to $12 \mathrm{~cm}$-long per cutting, in average (Table 2). Such great rooting percentage may be compared to percentages obtained by Bona et al. (2010) in $L$. dentata, a Lavandula species which was considered easy to root.

Table 2. Rooting percentage (RP) and averages of root number (RN) and length of the longest root (RL) per cutting of three genotypes (G1, G2 and G8) of Lavandula angustifolia treated with different concentrations of indole-3-butyric acid (IBA).

\begin{tabular}{|c|c|c|c|c|c|c|c|c|c|}
\hline \multirow{2}{*}{$\begin{array}{l}\text { IBA } \\
\left(\mathrm{mg} \mathrm{L}^{-1}\right)\end{array}$} & \multicolumn{3}{|c|}{ RP (\%) } & \multicolumn{3}{|c|}{$\mathrm{RN}$} & \multicolumn{3}{|c|}{$\mathrm{RL}(\mathrm{cm})$} \\
\hline & G1 & G2 & G8* & G1 & G2* & G8* & G1 & G2* & G8* \\
\hline 0 & $100,0 \mathrm{a}$ & $50,0 \mathrm{a}$ & $58,3 \mathrm{a}$ & $18,1 \mathrm{a}$ & $5,9 \mathrm{a}$ & $6,7 \mathrm{a}$ & $10,2 \mathrm{a}$ & $6,7 \mathrm{a}$ & $6,7 \mathrm{a}$ \\
\hline 1500 & $88,7 \mathrm{a}$ & $58,3 \mathrm{a}$ & $25,0 \mathrm{ab}$ & $22,7 \mathrm{a}$ & $4,3 \mathrm{a}$ & $4,5 \mathrm{a}$ & $11,9 \mathrm{a}$ & $6,9 \mathrm{a}$ & $5,4 a b$ \\
\hline 2000 & $100,0 \mathrm{a}$ & $50,0 \mathrm{a}$ & $0,0 \mathrm{~b}$ & $22,2 \mathrm{a}$ & $5,4 \mathrm{a}$ & $0,0 \mathrm{a}$ & $11,4 \mathrm{a}$ & $6,6 \mathrm{a}$ & $0,0 \mathrm{~b}$ \\
\hline C.V. $(\%)$ & 5,8 & 24,9 & 19,2 & 25,1 & 5,7 & 7,9 & 6,4 & 4,6 & 7,7 \\
\hline
\end{tabular}

* Original data was transformed $(\log \mathrm{x}+10)$.

Means followed by the same letter are not significantly different at $P=0.05$ (Tukey's multiple comparison).

Auxin did not influence rooting on G2 either, which presented approximately 50\% rooting, with five roots, 6-7 cm-long per cutting, in average (Table 2). Trevisan et al. (2008), similarly, observed no influence of auxin on rooting of blueberry herbaceous cuttings, and that cultivars presented differentiated genetic rooting potential. Naphthalene acetic acid (NAA) was also dispensable for rooting of Mikania micrantha cuttings (FERRIANI et al., 2007).
There was no statistical difference among treatments for $\mathrm{G} 3$, however, $700 \mathrm{mg} \mathrm{L}^{-1}$ IBA promoted $91.7 \%$ rooting, more than the control, which was $70.8 \%$. Rooting decreased with the greater doses (1500 and $2000 \mathrm{mg} \mathrm{L}^{-1}$ ) to $70.8 \%$ and $58.3 \%$, respectively. Root number, on the other hand, was greater with the two higher doses, while length of roots followed the behavior of the root percentage variable (Table 3 ). Response in rooting percentage and root number may differ for same doses, as reported by Herrera, Ono and Leal (2004), 
when inducing rooting in laurel cuttings with IBA; and in fig, IBA influenced rooting percentage but not root length (PIO et al., 2003). Herein, similarly to results obtained by Blythe et al. (2003) on cuttings of Hedera helix, although auxin was not essential for rooting, root percentage and length were greater when treated with IBA. Bona et al. (2010) observed that percentage of roots of $L$. dentata increased with IBA application and a quadratic regression was obtained for root number, being $2000 \mathrm{mg} \mathrm{L}^{-1}$ considered the best IBA concentration.

Table 3. Rooting percentage (RP) and averages of root number (RN) and length of the longest root (RL) per cutting of three genotypes (G3, G4 and G5) of Lavandula angustifolia treated with different concentrations of indole-3-butyric acid (IBA).

\begin{tabular}{lccccccccc}
\hline \multirow{2}{*}{$\begin{array}{l}\text { IBA } \\
\left(\mathrm{mg} \mathrm{L}^{-1}\right)\end{array}$} & $\mathrm{G} 3$ & $\mathrm{GP}(\%)$ & $\mathrm{G} 5^{*}$ & $\mathrm{G} 3^{*}$ & $\mathrm{G} 4 *$ & $\mathrm{G} 5^{*}$ & $\mathrm{G} 3^{*}$ & $\mathrm{G} 4^{*}$ & $\mathrm{G} 5^{*}$ \\
\hline 0 & $70,8 \mathrm{a}$ & $16,7 \mathrm{bc}$ & $25,0 \mathrm{a}$ & $7,8 \mathrm{a}$ & $4,5 \mathrm{a}$ & $4,3 \mathrm{a}$ & $9,6 \mathrm{a}$ & $5,5 \mathrm{a}$ & $5,8 \mathrm{a}$ \\
700 & $91,7 \mathrm{a}$ & $12,5 \mathrm{c}$ & $0,0 \mathrm{a}$ & $7,7 \mathrm{a}$ & $3,0 \mathrm{a}$ & $0,0 \mathrm{a}$ & $7,4 \mathrm{a}$ & $3,1 \mathrm{a}$ & $0,0 \mathrm{a}$ \\
1500 & $70,8 \mathrm{a}$ & $33,3 \mathrm{ab}$ & $8,3 \mathrm{a}$ & $10,1 \mathrm{a}$ & $6,0 \mathrm{a}$ & $0,3 \mathrm{a}$ & $12,1 \mathrm{a}$ & $5,6 \mathrm{a}$ & $3,7 \mathrm{a}$ \\
2000 & $58,3 \mathrm{a}$ & $37,5 \mathrm{a}$ & $8,3 \mathrm{a}$ & $10,1 \mathrm{a}$ & $4,8 \mathrm{a}$ & $2,0 \mathrm{a}$ & $9,5 \mathrm{a}$ & $6,8 \mathrm{a}$ & $0,3 \mathrm{a}$ \\
\hline C.V. $(\%)$ & 19,8 & 5,9 & 24,8 & 4,8 & 6,4 & 8,7 & 3,8 & 8,2 & 11,4 \\
\hline
\end{tabular}

*Original data was transformed $(\log \mathrm{x}+10)$.

Means followed by the same letter are not significantly different at $P=0.05$ (Tukey's multiple comparison).

For G4, greater percentage of roots was obtained with $2000 \mathrm{mg} \mathrm{L}^{-1}$ of IBA but did not differ statistically from the $1500 \mathrm{mg} \mathrm{L}^{-1}$ dose, which induced formation of more roots (Table 3 ). The same dose (2000 mg $\left.\mathrm{L}^{-1}\right)$ also induced greater root percentage and root number on japanese apricot cuttings (CHAGAS et al., 2008). IBA also influenced rooting of cuttings of Allamanda cathartica, an ornamental species (LOSS et al., 2008).

Auxin seemed to be detrimental to G5, but not statistically different from the other treatments. The control was superior for all the variables tested (Table 3). Auxin may have been toxic to this genotype, similarly to what happened to Acca sellowiana herbaceous cuttings, which suffered from AIB toxicity when higher doses were used (FRANZON; ANTUNES; RASEIRA, 2004).

The $1500 \mathrm{mg} \mathrm{L}^{-1}$ of IBA treatment induced greater percentage, number and length of roots for G6, but it was not statistically superior to the other treatments (Table 4). Higher doses of IBA promoted greater rooting percentage on Jatropha curcas cuttings, but it was not a significant effect either (NOOR CAMELLIA et al., 2009).

Table 4. Rooting percentage (RP) and averages of root number (RN) and length of the longest root (RL) per cutting of two genotypes (G6 and G7) of Lavandula angustifolia treated with different concentrations of indole-3-butyric acid (IBA).

\begin{tabular}{lcccccc}
\hline IBA & \multicolumn{2}{c}{$\mathrm{RP}(\%)$} & \multicolumn{2}{c}{$\mathrm{RN}$} & \multicolumn{2}{c}{$\mathrm{RL}(\mathrm{cm})$} \\
\cline { 2 - 7 }$\left(\mathrm{mg} \mathrm{L}^{-1}\right)$ & $\mathrm{G}^{*}$ & $\mathrm{G}^{*}$ & $\mathrm{G}^{*}$ & $\mathrm{G}^{*}$ & $\mathrm{G} 6^{*}$ & $\mathrm{G}^{*}$ \\
\hline 0 & $6,7 \mathrm{a}$ & $58,3 \mathrm{a}$ & $1,0 \mathrm{a}$ & $8,4 \mathrm{a}$ & $1,8 \mathrm{ab}$ & $8,0 \mathrm{a}$ \\
700 & $6,7 \mathrm{a}$ & $54,1 \mathrm{a}$ & $1,0 \mathrm{a}$ & $5,4 \mathrm{a}$ & $0,3 \mathrm{~b}$ & $7,6 \mathrm{a}$ \\
1500 & $26,7 \mathrm{a}$ & $45,8 \mathrm{a}$ & $4,2 \mathrm{a}$ & $6,2 \mathrm{a}$ & $7,5 \mathrm{a}$ & $7,5 \mathrm{a}$ \\
\hline C.V. $(\%)$ & 18,3 & 5,7 & 7,0 & 5,3 & 6,4 & 2,4 \\
\hline
\end{tabular}

*Original data was transformed $(\log \mathrm{x}+10)$.

Means followed by the same letter are not significantly different at $P=0.05$ (Tukey's multiple comparison). 
Rooting of G7 was not influenced by auxin application (Table 4). NAA application did not influence, as well, rooting initiation of Mikania micrantha cuttings (FERRIANI et al., 2007).

For G8, the control was statistically superior to the $1500 \mathrm{mg} \mathrm{L}^{-1}$ treatment, but did not differ from the $700 \mathrm{mg} \mathrm{L}^{-1}$ treatment (Table 2). As also observed by Ferriani et al. (2007) with NAA on cutting propagation of Mikania micrantha cuttings, auxin herein was dispensable.

Briefly, G1 and G3 presented high rooting percentages, in spite of $L$. angustifolia being considered a hard to root species. G4, G5 and G6, however, presented very poor rooting, compared to the other genotypes (Tables 2-4). IBA did not exert influence on rooting of $\mathrm{G} 1, \mathrm{G} 2$, and $\mathrm{G} 7$; was benefic to $\mathrm{G} 3$ until $700 \mathrm{mg} \mathrm{L}^{-1}$; was benefic to $\mathrm{G} 4$ and G6; and was prejudicial to G5 and G8; the same IBA dose which promoted better rooting on G3 (700 mg $\mathrm{L}^{-1}$ ) was toxic to $\mathrm{G} 5 ; 1500 \mathrm{mg} \mathrm{L}^{-1}$ of IBA promoted better rooting, greater root number and length on G6 but was completely and significantly detrimental to G8. Or else, same species genotypes, from different provenances, presented very diverse response to IBA application. Bray, Rom and Clark (2003) observed significant interactions for cultivar and IBA treatment for rooting of blackberries cuttings, where 'Apache' had the highest rooting percentage, and 'Arapaho' and 'Navaho' the lowest. Kesari, Das and Rangan (2010) also observed that the interaction among auxins and genotypes had a significant effect on root induction and differentiation of Pongamia pinnata cuttings.

Depending on the endogenous level of growth regulating substance, exogenous application of auxin may be promotive, ineffective or even inhibitory for the rooting of cuttings and such difference in rooting ability may be explained by the different physiological states (KESARI; DAS; RANGAN, 2010) and by different type of cutting (BETANIN; NIENOW, 2010). These authors observed that IBA application did not influence rooting of Erythrina falcata stem cuttings, but promoted rooting of leaf cuttings.

Slightly different cutting sizes were used due to the different sizes of the plant stock stems, which may also have exerted some influence on rooting response. In Melaleuca alternifolia, 10-cm long cuttings presented approximately 20\% more roots than 15-cm long cuttings (OLIVEIRA et al., 2008). An inverse behavior was observed by Bona et al. (2004) on Baccharis spp cuttings.

\section{Conclusion}

Necessity of auxin application and adequate dose may not be generalized to L. angustifolia different accessions. Its use should be incentivized when the genotype is recalcitrant to root and auxin concentration should be adjusted to it.

\section{References}

ATROCH, A. L.; CRAVO, M. S.; SANTOS, J. A. Enraizamento de estacas de clones de guaranazeiro tratadas com ácido-3-indol-butírico (AIB). Revista Ciências Agrárias, Belém, v. 47, n. 47, p. 103-111, 2007.

BETANIN, L.; NIENOW, A. A. Propagação vegetativa da corticeira-da-serra (Erythrina falcata Benth.) por estaquia caulinar e foliar. Semina: Ciências Agrárias, Londrina, v. 31, n. 4, p. 871-880, 2010.

BEUS, C. Growing and marketing lavender. Washington: Washington State University, 2006. 28 p.

BIASI, L. A.; DESCHAMPS, C. Plantas aromáticas: do cultivo à produção de óleo essencial. Curitiba: Layer Studio Gráfico e Editora, 2009. 160 p.

BLYTHE, E. K.; SIBLEY, J. L.; TILT, K. M.; RUTER, J. M. Cutting propagation with auxin applied via a stabilized organic rooting substrate. Combined Proceedings International Plant Propagators' Society, Seattle, v. 53, p. 275-283, 2003.

BONA, C. M.; BIASI, L. A.; LIPSKI, B.; MASETTO, M. A. M.; DESCHAMPS, C. Adventitious rooting of auxin-treated Lavandula dentata cuttings. Ciência Rural, Santa Maria, v. 40, n. 5, p. 1210-1213, 2010. 
BONA, C. M.; BIASI, L. A.; ZANETTE, F.; NAKASHIMA, T. Propagation of three species of Baccharis using different cutting lengths. Semina: Ciências Agrárias, Londrina, v. 25, n. 3, p. 179-184, 2004.

BRAY, M. M; ROM, C. R.; CLARK, J. R. Propagation of thornless Arkansas blackberries by hardwood cuttings. Horticultural Studies, Fayetteville, n. 520, p. 10-13, 2003.

CAVANAGH, H. M. A.; WILKINSON, J. M. Biological activities of lavender essential oil. Phytotherapy Research, Malden, v. 16, n. 4, p. 301-308, 2002.

CHAGAS, E. A.; PIO, R.; BETTIOL NETO, J. E.; SOBIERAJSKI, G. R.; DALL'ORTO, F. A. C.; SIGNORINI, G. Rooting of peach and clones of japanese apricot cutting treated with IBA. Ciência $e$ Agrotecnologia, Lavras, v. 32, n. 3, p. 986-991, 2008.

CHIVERS, I. H.; ALDOUS, D. E. Reproductive and vegetative responses of different accessions of Microlaena stipoides (Labill.) R.Br. to nitrogen applications and supplementary irrigation in southern Australia. The Rangeland Journal, Collingwood, v. 27, n. 2, p. 151-157, 2005.

EHLERT, B.; HINCHA, D. K. Chlorophyll fluorescence imaging accurately quantifies freezing damage and cold acclimation responses in Arabidopsis leaves. Plant Methods, London, v. 4, n. 12, p. 1-7, 2008.

FACHINELLO, J. C.; HOFFMANN, A.; NACHTIGAL, J. C. Propagação de plantas frutíferas de clima temperado. Pelotas: UFPel. 1995. 178 p.

FERRIANI, A. P.; BORGES, M. V.; ZUFFELLAT0RIBAS, K. C.; CARPANEZZI, A. A.; KOEHLER, H. S. Influência da época do ano e das diferentes formas de aplicação de ácido naftaleno acético (ANA) no enraizamento de Mikania micrantha Kunth. Revista Brasileira de Plantas Medicinais, Botucatu, v. 9, n. 2, p. 102-107, 2007.

FIORENO, A. New uses for essential oils could herald wave of growth. Chemical Market Reporter, Milwaukee, v. 251 , n. 18 , p. $24,1997$.

FRANCIS D.; SORRELL, D. A. The interface between the cell cycle and plant growth regulators: a mini review. Plant Growth Regulation, Dordrescht, v. 33, n. 1, p. 1-12, 2001.

FRANZON, R. C.; ANTUNES, L. E. C.; RASEIRA, M. C. B. Efeito do AIB e de diferentes tipos de estaca na propagação vegetativa da goiabeira-serrana (Acca sellowiana Berg). Revista Brasileira de Agrociência, Pelotas, v. 10, n. 4, p. 515-518, 2004.
GIAKOUNTIS, A.; CREMER, F.; SIM, S.; REYMOND, M.; SCHIMITT, J.; COUPLAND, G. Distinct patterns of genetic variation alter flowering responses of Arabidopsis accessions to different daylengths. Plant Physiology, Danvers, v. 152, n. 1, p. 177-191, 2010.

HARTMANN, H. T.; KESTER, D. E.; DAVIES JUNIOR, F. T.; GENEVE, R. L. Plant propagation: principles and practices. 7. ed. New Jersey: Prentice Hall, 2002, 880 p.

HERRERA, T. I.; ONO, E. O.; LEAL, F. P. Efeitos de auxina e boro no enraizamento adventíceo de estacas caulinares de louro (Laurus nobilis L.). Biotemas, Florianópolis, v. 17, n. 1, p. 65-77, 2004.

KESARI, V.; DAS, A.; RANGAN, L. Effect of genotype and auxin treatments on rooting response in stem cuttings of CPTs of Pongamia pinnata, a potential biodiesel legume crop. Current Science, Columbus, v. 98, n. 9, p. 1234-1237, 2010.

LORENZI, H. E.; MATOS, F. J. de A. Plantas medicinais no Brasil/nativas e exóticas. Nova Odessa: Instituto Plantarum. 2002. 512 p.

LOSS, A.; TEIXEIRA, M. B.; ASSUNÇÃO, G. M.; HAIM, P. G.; LOUREIRO, D. C.; SOUZA, J. R. Enraizamento de estacas de Allamanda cathartica L. tratadas com ácido indolbutírico (AIB). Revista Brasileira de Ciências Agrárias, Recife, v. 3, n. 4, p. 313316, 2008.

MISHRA, B. S.; SINGH, M.; AGGRAWAL, P.; LAXMI, A. Glucose and auxin signaling interaction in controlling Arabidopsis thaliana seedlings root growth and development. PLoS ONE, San Francisco, v. 4, n. 2, p. 1-13, 2009.

MOON, T.; WILKINSON, J. M.; CAVANAGH, H. M. A. Antibacterial activity of essential oils, hydrosols and plant extracts from Australian grown Lavandula spp. The International Journal of Aromatherapy, Oxford, v. 16, n. 1, p. 9-14. 2006.

NOOR CAMELLIA, N. A.; THOHIRAH, L. A.; ABDULLAH, N.A. P.; MOHD KHIDIR, O. Improvement on rooting quality of Jatropha curcas using indole butyric acid (IBA). Research Journal of Agriculture and Biological Sciences, Ma'an, v. 5, n .4, p. 338-343, 2009.

OLIVEIRA, Y.; SILVA, A. L. L.; PINTO, F.; QUOIRIN, M.; BIASI, L. A. Comprimento das estacas no enraizamento de melaleuca. Scientia Agraria, Curitiba, v. 9 , n. 3, p. 415-418, 2008.

PASQUAL, M.; CHALFUN, N. N. J.; RAMOS, J. D.; VALE, M. R.; SILVA, C. R. R. Fruticultura comercial: propagação de plantas frutíferas. Lavras: UFLA/FAEPE, 2001. 137 p. 
PAVLOV, A. L.; GEORGIEV, M. L.; PANCHEV, I. N.; ILIEVA, M. P. Optimization of rosmarinic acid production by Lavandula vera MM plant cell suspension in a laboratory bioreactor. Biotechnology Progress, Pittsburgh, v. 21, n. 2, p. 394-396. 2005.

PIO, R.; RAMOS, J. D.; CHALFUN, N. N. J.; COELHO, J. H. C.; GONTIJO, T. C. A.; CARRIJO, E. Enraizamento de estacas apicais de figueira tratadas com sacarose e ácido indolbutírico por imersão rápida. Revista Brasileira de Agrociência, Pelotas, v. 9, n. 1, p. 35-38, 2003.

SUDRIA, C.; PALAZON, J.; CUSIDO, R.; BONFILL, M.; PINOL, M. T.; MORALES, C. Effect of benzyladenine and indolebutyric acid on ultrastructure, glands formation, and essential oil accumulation in Lavandula dentata plantlets. Biologia Plantarum, Praha, v. 44, n. 1, p. 1-6, 2001.

TREVISAN, R.; FRANZON, R. C.; FRITSCHE NETO, R.; GONÇALVES, R. S.; GONÇALVES, E. D.; ANTUNES, L. E. C. Enraizamento de estacas herbáceas de mirtilo: influência da lesão na base e do ácido indolbutírico. Ciência e Agrotecnologia, Lavras, v. 32, n. 2, p. 402-406, 2008.

TYUB, S.; KAMILI, A. N.; SHAH, A. M. Effect of BAP on shoot regeneration in shoot tip cultures of Lavandula officinalis. Journal of Research \& Development, Srinagar, v. 7, p. 125-130, 2007. 